Journal of Social Sciences and Politics

Vol. 7 No. 2 April 2020

p-ISSN : 2252-4150

e-ISSN : 2716-3474

Tersedia online di http://ejurnal.stisipolcandradimuka.ac.id/index.php/JurnalPublisitas/

\title{
Strategi Komunikasi Pemasaran Dalam Menarik Minat Konsumen Untuk Menggunakan Jasa Pembiayaan Multiguna BESS FINANCE Di Kota Baturaja
}

\author{
Herwandi Agustian $^{1}$, Ira Purwitasari ${ }^{2}$, Fathurrijal ${ }^{3}$ \\ ${ }^{1}$ Program Studi Ilmu Komunikasi, STISIPOL Candradimuka \\ ${ }^{2}$ Program Studi Ilmu Komunikasi Universitas Mercu Buana \\ ${ }^{3}$ Komunikasi dan Penyiaran Islam FAI, Universitas Muhammadiyah Mataram \\ E-mail: herwandi.agustian@ @stisipolcandradimuka.ac.id ${ }^{1}$ \\ E-mail: ira_purwitasari@mercubuana.ac.id ${ }^{2}$ \\ E-mail: fathurrija19@gmail.com ${ }^{3}$
}

\begin{abstract}
ABSTRAK
Penelitian ini bertujuan untuk mengetahui strategi komunikasi pemasaran dalam menarik nasabah agar menggunakan jasa pembiayaan multiguna Bess Finance. Metode penelitian yang digunakan adalah deskriptif kualitatif. Pengumpulan data dilakukan melalui observasi, wawancara, dokumentasi dan studi pustaka. Adapun wawancara mendalam dilakukan terhadap 3 narasumber yang merupakan pihak internal PT. Bess Finance yang terkait langsung dengan pelaksanaan komunikasi pemasaran di perusahaan jasa tersebut dan 2 orang nasabah yang berdomisili di Palembang. Berdasarkan analisis konsep model AIDA ini, hasil penelitian menunjukkan bahwa bagaimana proses pemasaran dengan mengenalkan jasa yang ditawarkan mampu memengaruhi minat nasabah dalam melakukan pengambilan keputusan untuk mempercayai dan menggunakan jasa pembiayaan multiguna PT.Bess Finance.
\end{abstract}

Kata kunci : komunikasi, pemasaran, komunikasi pemasaran,

\begin{abstract}
This study aims to determine marketing communication strategies in attracting customers to use Bess Finance multipurpose financing services. The research method used is descriptive qualitative. Data collection was carried out through observation, interviews, documentation and literature study. The in-depth interviews were conducted with 3 speakers who were internal parties of PT. Bess Finance which is directly related to the implementation of marketing communications at the service company and 2 customers who are domiciled in Palembang. Based on the analysis of the concept of the AIDA model, the results show that how the marketing process by introducing the services offered is able to influence customer interest in making decisions to trust and use Bess Finance multipurpose financing services.
\end{abstract}

Keywords: communication, marketing, marketing communication 


\section{PENDAHULUAN}

Perkembangan bisnis yang semakin kompetitif telah mendorong berbagai perusahaan untuk mampu memahami pelanggannnya dengan lebih baik karena pelanggan merupakan fokus utama dari keberadaan suatu perusahaan. Semakin memahami pelanggan maka semakin kuat perusahaan untuk berkompetisi dengan pesaingnya. Salah satu kunci utama dari pemahaman perusahaan terhadap pelanggan adalah adanya komunikasi yang efektif sehingga pesan yang disampaikan oleh perusahan terhadap pelanggannya bisa utuh dan dipahami dengan baik oleh pelanggan (Priansa, 2017 : 93).

Komunikasi yang terjadi antara peruahaan dan konsumen disebut juga sebagai komunikasi kepada konsumen. Komunikasi kepada konsumen jauh lebih rumit dan kompleks dibandingkan komunikasi personal. Komunikasi konsumen melibatkan konsumen dalam jumlah yang besar. Komunikasi kepada konsumen merupakan pertukaran ide, gagasan, masukan, informasi dan kritik yang memeiliki tujuan tertentu, disajikan secara personal ataupun impersonal melalui symbol-simbol atau sinyal-sinyal sehingga pesan dari perusahaan ataupun dari konsumen dapat dipahami dengan efektif.

Keterampilan pimpinan dan pegawai untuk berkomunikasi dalam berbagai bentuk komunikasi kepada konsumen akan menentukan tingkat keberhasilan perusahaan dalam mencapai tujuannya. Komunikasi konsumen yang buruk akan menyebabkan citra perusahaan buruk. Oleh karena itu, pimpinan dan pegawai perlu melaksanakan kegiatan komunikasi kepada konsumen secara baik (Priansa, 2017; 1-2).

Komunikasidapat membangkitkan emosi yang menempatkan para konsumen dalan kerangka berpikir yang lebih reseptif dan dapat mendorong pembelian yang membantu konsumen memecahkan berbagai masalah atau menghindari hasil yang negatif. Dengan kata lain, komunikasi merupakan mediator antara pemasar dan konsumen dan antara konsumen dengan lingkungan sosiokultural mereka (Schiffman, Leon; Kanuk, 2008: 252). "Komunikasi pemasaran merupakan usaha untuk menyampaikan pesan kepada public terutama konsumen sasaran mengenai keberadaan produk di pasar" (Sutisna, 2001: 267). Komunikasi pemasaran memegang peranan yang sangat penting bagi pemasar. Tanpa komunikasi maka konsumen maupun masyarakat secara keseluruhan tidak akan mengetahui keberadaan produk di pasar.

PT.Bentara Sinergies Multifinance atau yang lebih dikenal dengan nama PT. BESS Finance. Bergerak dalam bidang pembiayaan konsumen. Sebagai langkah awal PT. BESS Finance menjalankan usahanya dengan membuka beberapa jaringan kantor yang terletak di Jakarta, Tangerang, Pondok Pinang, Depok, Bekasi, Cikarang dan Serang. Dengan visi menjadi "Perusahaan Multifinance Pilihan Konsumen Yang Terbaik" hingga saat ini BESS Finance telah memperluas jaringan usahanya hingga wilayah Jakarta, Banten, Jawa Barat, Jawa Tengah, Jawa Timur, Sumbagsel, Sumbagut, Sulawesi dan Kalimantan. Dan PT. Bess Finance cabang kota Baturaja didirikan pada tahun 2011, merupakan salah satu cabang pembayaran multiguna yang menawarkan berbagai macam penawaran yang dapat menjadi salah satu pertimbangan konsumen untuk menggunakan jasa mutliguna PT. Bess Finance (www.bess.co.id, Sabtu 06/05/2017).

Stategi komunikasi pemasaran yang di implemetasikan dalam perusahaan ini menggunakan berbagai macam cara diantarnya direct sales, canvassing dan door to door. Sebagai 
sebuah perusahaan jasa, penting bagi PT. Bess Finance untuk membangun kepercayaan konsumennya melalui komunikasi yang interaktif dengan pelanggannya. PT Bess Finance mengintegrasikan berbagai macam komunikasi untuk menciptakan kejelasan dan konsistensi pesan serta sinergi antar media yang digunakan. Hal ini merupakan hal yang sangat penting mengingat jenis layanan jasa keuangan sangat menekankan faktor trust maka dibutuhkan berbagai media, alat dan teknologi yang bisa dimanfaatkan dalam mengelola system komunikasi pemasaran yang kompleks.

Hal yang menarik dari jasa pembiayaan multiguna dimana sekarang banyak sekali masyarakat yang membutuhkan pinjaman uang untuk biaya kehidupan yang semakin sulit, baik itu untuk guna usaha, pedagangan, anjak piutang dan pembiayaan lainnya. Dengan banyaknya bermunculan jasa pembiayaan yang ada saat ini telah menciptakan persaingan yang sangat ketat sehingga tidak dapat dihindari perusahaanperusahaan yang bergerak di layanan jasa pembiayaan ini harus memiliki strategi pemasaran tersendiri untuk dapat menarik nasabah sebanyak mungkin. Dari latar belakang di atas penulis tertarik untuk meneliti strategi komunikasi pemasaran dalam menarik nasabah untuk menggunakan jasa pembiayaan PT Bess Finance.

\section{TINJAUAN PUSTAKA}

Kata/istilah komunikasi berpangkal pada perkataan lain Communis yang artinya membuat kebersamaan atau membangun kebersamaan antara dua orang atau lebih. Komunikasi juga berasal dari akar kata latin Communico yang artinya membagi Cherry dalam Stuart seperti dikutip (Cangara, 2012:20).

Komunikasi adalah proses penyampaian pesan dari komunikator kepada komunikan melalui media tertentu untuk menghasilkan efek/tujuan dengan mengharapkan feedback atau umpan balik. Tujuan utama komunikasi adalah untuk membangun/menciptakan pemahaman atau pengertian bersama. Saling memahami atau mengerti bukan berarti harus menyetujui, tetapi mungkin dengan komunikasi terjadi suatu perubahan sikap, pendapat, perilaku, ataupun perubahan secara sosial (Daryanto, 2010:148).

Adapun faktor-faktor yang menjadi dasar dalam komunikasi mencakup komunikator (sumber pesan), pesan (informasi yang disampaikan), media (saluran/ alat penyampaian pesan), pengaruh (efek/ timbal balik setelah menerima pesan). Komunikasi merupakan suatu "bentuk kegiatan". Penyampaian pesan dari sumber pesan kepada penerima pesan. Oleh karena itu, komunikasi efektif dapat diartikan sebagai suatu kegiatan komunikasi yang dapat mencapai hasil (output) sebagaimana yang diharapkan (target) dan termuat dalam pesan tersebut serta dapat memberikan kemanfaatan (benefit) yang besar kepada sasaran komunikasi atau penerima pesan (Daryanto, 2010: 59).

Fungsi marketing pada perusahaan, [1] Fungsi pertukaran, [2] Fungsi distribusi fisik, dan [3] Fungsi perantara. Adapun beberapa fungsi lain dari divisi marketing pada perusahaan adalah sebagai berikut ini: [1] Marketing berperan sebagai sales. [2] Marketing berperan sebagai promosi. [3] Marketing sebagai riset dan pengembangan. [4] Marketing berperan sebagai perwujudan konsep marketing communication atau komunikasi pemasaran.

\section{Komunikasi Pemasaran}

Komunikasi pemasaran meliputi tiga tujuan utama yaitu menyebarkan informasi (komunikasi informatif), 
memengaruhi untuk melakukan pembelian atau menarik konsumen (komunikasi persuasif), dan mengingatkan khalayak untuk melakukan pembelian ulang (komunikasi mengingatkan kembali). Tujuan komunikasi pemasaran pada dasarnya adalah memberikan efek berikut:

[1] Efek kognitif, yaitu membentuk kesadaran informasi tertentu dalam benak pelanggan;

[2] Efek afektif, yaitu memberikan pengaruh untuk melakukan sesuatu yang diharapkan adalah reaksi pembelian dari pelanggan;

[3] Efek konatif dan perilaku, yaitu membentuk pola khalayak menjadi perilaku selanjutnya. Perilaku yang diharapkan adalah pembelian ulang.

\section{Konsep Model AIDA ( Attention, Intrest, Disere, Action)}

Tujuan komunikasi pemasaran yang penting adalah memunculkan tanggapan pelanggan. Model AIDA merupakan salah satu model hierarki tanggapan audiens yang mengasumsikan bahwa pembelian melewati tahapan kognitif, pengaruh, dan perilaku secara berturut-turut sebagaimana yang dijelaskan di bawah ini :

1. A (Attention), yang mempunyai arti memberi kesan menarik, dan perhatian kepada calon pembeli/ konsumen. Apabila perusahaan ingin memperkenalkan produk/ jasa yang akan dijual inilah yang pertama sekali digunakan, maka perusahaan harus mampu menarik perhatian calon pembeli/ konsumen dengan menggunakan bahasa tubuh yang positif yang mencerminkan sebuah keyakinan betapa pentingnya produk/ jasa bermanfaat kepada calon pembeli/ konsumen sehingga dapat benar-benar menginginkannya.
2. I (Interest), yang berarti adanya rasa ketertarikan yang sangat besar. Setelah berhasil melewati langkah A (Attention), maka langkah ini merupakan fase keduanya. Rasa ketertarikan akan timbul setelah calon pembeli/ konsumen yakni akan produk/ jasa yang ditawarkan. Pemasaran dalam fase ini memberikan sebuah gambaran singkat mengenai produk/ jasa yang ditawarkan.

3. D (Desire), yang mempunyai arti membuat keinginan. Apabila telah berhasil melakukan Interest, berarti telah menciptakan sebuah keinginan untuk mengetahui lebih lanjut dan lebih banyak mengenai produk/ jasa ditawarkan. Konsep ini diperjelas dengan adanya sebuah rasa saling melengkapi. Artinya apakah produk/ jasa tersebut dapat melengkapi kebutuhan yang inginkan.

4. A (Action), yang mempunyai arti sebuah tindakan atau perbuatan yang dilakukuan sesuai dengan kemauan seseorang.

\section{Kerangka Pikir}

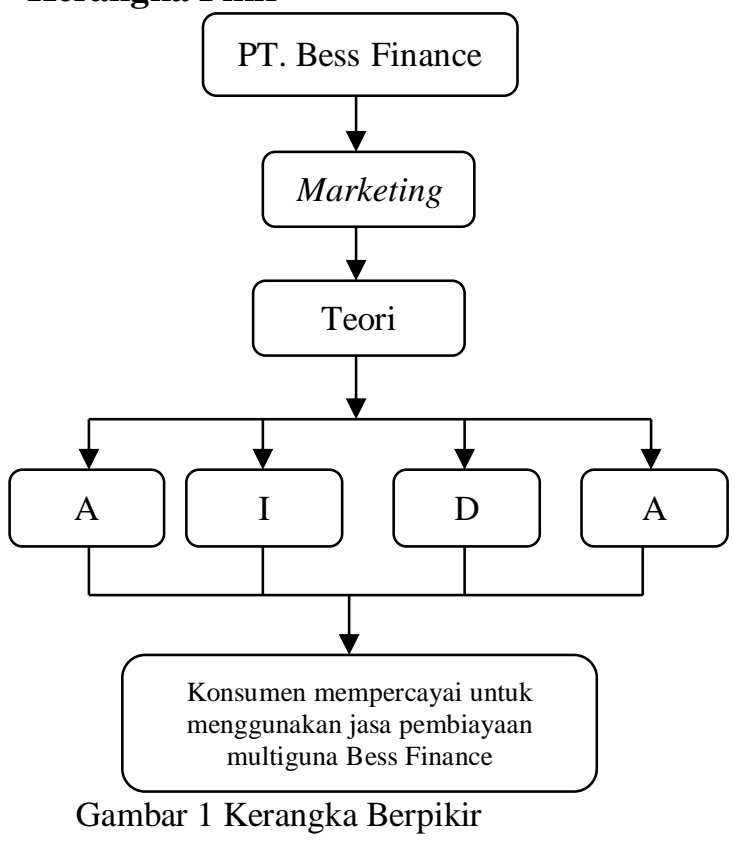

3. METODE PENELITIAN

\section{Jenis Penelitian}


Metode penelitian menggunakan metode penelitian kualitatif. Dalam penelitian ini wawancara mendalam (Dept interview) akan dilakukan dengan pihak PT. Bess Finance, maupun lingkungan konsumen yang menjadi objek dalam penelitian.

\section{Fokus Penelitian}

Berdasarkan rumusan masalah dan tujuan penelitian maka fokus penelitian adalah untu mengetahui strategi dan pola komunikasi pemasaran dalam menarik minat konsumen untuk menggunakan jasa pembiayaan multiguna PT. Bess Finance.

\section{Informan Penelitian}

Dalam konteks purposive sampling atau lebih disebut dengan erienterior based seletion. Penentuan informan menggunakan metode purposive sampling dimana informan itu dipilih adalah orang yang terkait dalam pihak PT. Bess Finance. Informan yang akan dijadikan referensi adalah didalam Tabel 1 .

Tabel 1. Informan Penelitian

\begin{tabular}{|c|l|l|}
\hline No & \multicolumn{1}{|c|}{ Informan } & \multicolumn{1}{c|}{ Jabatan } \\
\hline 1 & $\begin{array}{l}\text { Manumpak Tua } \\
\text { Simatupang }\end{array}$ & $\begin{array}{l}\text { BM Bess Finance } \\
\text { Cab. Baturaja }\end{array}$ \\
\hline 2 & Rumsah & Head Marketing \\
\hline 3 & Yuliani & Marketing \\
\hline 4 & Andri Agustinus & Konsumen \\
\hline 5 & Ujang Riadi & Konsumen \\
\hline
\end{tabular}

Sumber: diolah Penulis 2019

\section{Teknik Pengumpulan Data}

Data yang didapat dari sumber pertama baik individu ataupun perorangan, dari Wawancara (Interview), Observasi (Observation), Dokumentasi (Documentation), dan Studi Pustaka

\section{PEMBAHASAN}

Berdasarkan hasil penelitian yang telah dilakukan dapat diketahui bahwa variabel Attention (Perhatian) dalam menarik minat konsumen strategi komunikasi seorang marketing dalam berinteraksi dengan konsumen dapat mempengaruhi minat konsumen untuk memutuskan menggunakan jasa pembiayaaan yang ditawarkan. Perhatian pertama dari seorang pemasar terdahap konsumen dapat memperngaruhi tindakan konsumen yang selanjutnya. Apabila perhatian pertama dari pemasar sudah tidak baik maka konsumen pun tidak akan tertarik dengan jasa yang akan ditawarkan. Maka diharapkan pemasar lebih cermat dalam merancang suatu strategi komunikasi pemasaran agar konsumen tidak hanya memperhatikam saja pada saat seorang pemasar menjelaskan keunggulan jasa pembiayaan Bess Finance akan tetapi konsumen juga percaya dan menggunakan jasa pembiayaan multiguna Bess Finance.

$$
\text { Pada variabel Interest }
$$

(Ketertarikan) dalam menarik minat konsumen strategi komunikasi seorang marketing selanjutnya memasuki dalam tahap kedua yaitu ketertarikan, rasa ketertarikan akan timbul setelah calon pembeli/ konsumen yakin akan produk/ jasa yang ditawarkan oleh pemasar. Pemasaran dalam fase ini memberikan sebuah gambaran singkat mengenai produk/ jasa yang ditawarkan. Dalam fase ini pemasar menjelaskan keungguan dari jasa pembiayaan multiguna Bess Finance dengan strategi komunikasi yang tepat dan dibantu dengan penjelasan lewar brosur, maka pesan yang disampaikan untuk memengaruhi konsumen tersebut tercapai. Setelah menjelaskan keunggulan tersebut maka dalam diri konsumen akan timbul rasa ketertarikan yang lebih akan hal jasa pembiayaan multiguna Bess Finance tersebut. 
Pada variabel Desire (Keinginan) Apabila telah berhasil melakukan Interest, berarti telah menciptakan sebuah keinginan konsumen untuk mengetahui lebih lanjut dan lebih banyak mengenai produk/ jasa ditawarkan. Sebuah fakta membuktikan bahwa banyak yang melakukan hal tersebut dengan pengalaman yang sama. Menumbuhkan desire disini bukan hanya sekedar melakukan tugas pekerjaan, tetapi ini merupakan modal bagi pemasar untuk mencapai kesuksesan dalam menawarkan jasa/ produk yang dibawa.

Pada variabel Action (Tindakan atau perbuatan) yang dilakukan sesuai dengan kemauan seseorang. Langkah akhir dalam menerapkan teknik AIDA adalah action disini. Tindakan ini biasanya merupakan dorongan, motivasi agar calon pembeli/ konsumen melakukan tindakan, seperti membeli/ menggunakan atau bisa juga menolak dari penawaran tersebut. Dalam variabel action disini seorang marketing mampu memerankan perannya menggunakan strategi komunikasi untuk menarik minat konsumen agar konsumen percaya dan menggunakan jasa pembiayaan PT. Bess Finance atau menolaknya.

Berdasarkan analisis konsep model AIDA ini, dapat dijelaskan bahwa bagaimana proses pemasaran dengan mengenalkan jasa yang ditawarkan mampu

memengaruhi minat nasabah dalam melakukan pengambilan keputusan untuk mempercayai dan menggunakan jasa pembiayaan multiguna Bess Finance.

Tabel 2. Pemetaan Analisis Hasil Penelitian

\begin{tabular}{|c|c|c|}
\hline No & $\begin{array}{c}\text { Variabel } \\
\text { dalam } \\
\text { Teori }\end{array}$ & Analisis \\
\hline
\end{tabular}

\begin{tabular}{|c|c|c|}
\hline 1 & $\begin{array}{l}\text { A } \\
\text { (Attention) }\end{array}$ & 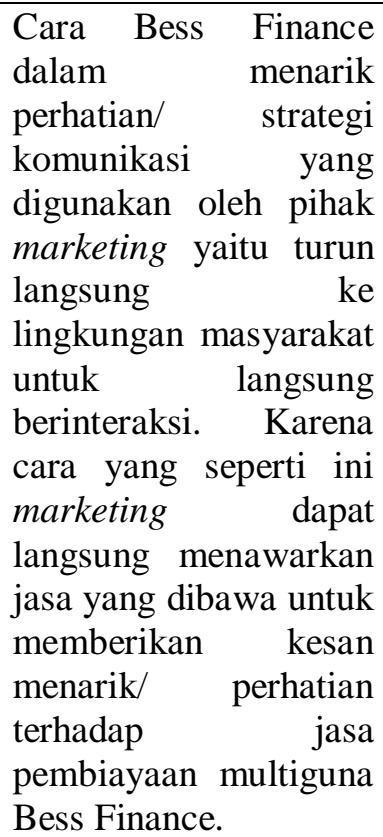 \\
\hline 2 & I (Interest) & $\begin{array}{l}\text { Setelah sukses } \\
\text { menjalankan Attention, } \\
\text { maka tahap selanjutnya } \\
\text { yaitu Interest atau yang } \\
\text { disebut dengan } \\
\text { ketertarikan. } \\
\text { Ketertarikan konsumen } \\
\text { itu timbul pada saat } \\
\text { pihak marketing Bess } \\
\text { Finance memberikan } \\
\text { penjelasan tetang } \\
\text { keunggulan yang ada } \\
\text { di jasa pembiayaan } \\
\text { multiguna Bess } \\
\text { Finance tersebut. }\end{array}$ \\
\hline 3 & D (Disire) & $\begin{array}{lr}\text { Pada tahap disire } & \text { yang } \\
\text { mempunyai } & \text { arti } \\
\text { membuat } & \text { sebuah } \\
\text { keinginan yang lebih. } & \text { ing } \\
\text { Dalam tahap } & \text { ini } \\
\text { marketing } & \text { Bess } \\
\text { Finance r sebisa } & \text { mungkin menimbulkan } \\
\text { keinginan tersebut } \\
\text { dengan cara melakukan } \\
\text { menyebar brosur } \\
\text { tentang Bess Finance } \\
\text { dan meletakkan iklan } \\
\text { pada tempat yang } \\
\text { ramai di kunjungi } \\
\text { masyarakat }\end{array}$ \\
\hline
\end{tabular}




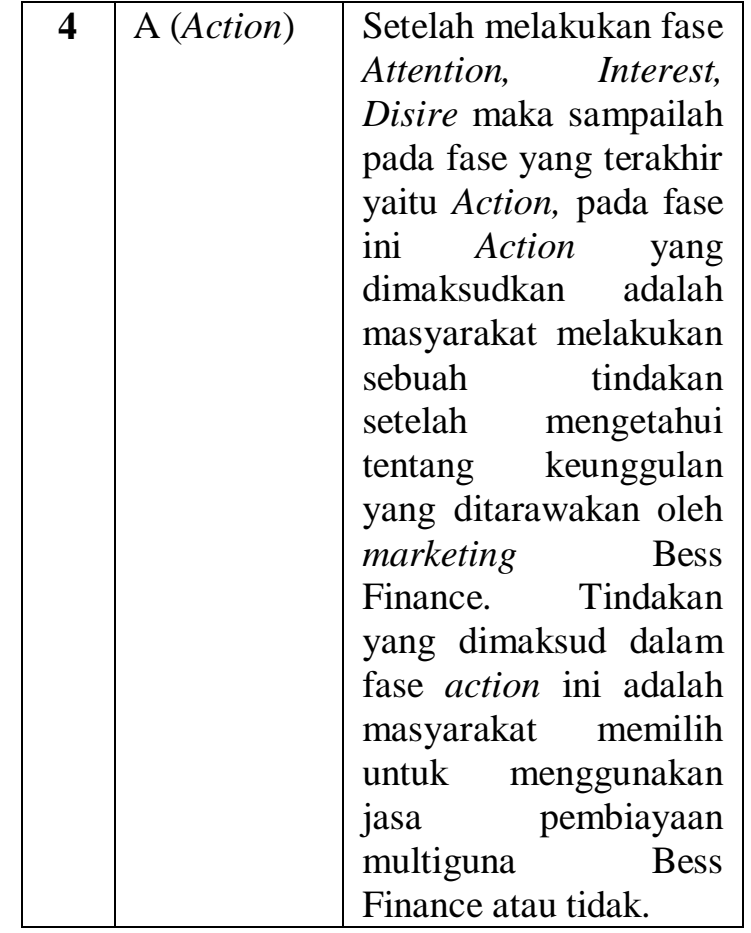

Sumber: diolah oleh Penulis 2019

\section{KESIMPULAN DAN SARAN Kesimpulan}

Berdasarkan uraian dari bab sebelumnya, maka peneliti dapat diambil kesimpulan sebagai berikut:

1. Penerapan Attention (Perhatian) dalam strategi marketing Bess Finance menerapkan strategi untuk turun langsung dalam lingkungan masyarakat untuk berinteraksi langsung dalam menawarkan jasa pembiayaan multiguna Bess Finance.

2. Penerapan Interest (Ketertarikan) marketing Bess Finance menerapkan strategi Interest dengan cara menawarkan keunggulan jasa pembiayaan multiguna Bess Finance dari yang lainnya.

3. Penerpan Desire (Keinginan) marketing Bess Finance menerapakan strategi Desire dengan cara lebih menekankan lagi tentang keunggulan dan keistimewaan dari jasa pembiayaan multiguna Bess Finance agar marketing berhasil menciptakan sebuah keinginan kepada kosumen untuk lebih ingin mengetahui mengenai jasa yang ditawarkan.

4. Penerapan Action (Tindakan) tindakan ini adalah sebuah respon yang ditimbulkan oleh konsumen setelah mendengarkan penjelasan tentang keunggulan jasa yang ditawarkan oleh marketing Bess Finance. Dengan menggunakan teori AIDA banyak konsumen menggunakan jasa pembiayaan multiguna Bess Finance. Apabila langkah awal pada Variabel Attention (Perhatian) strategi yang digunakan dapat memengaruhi konsumen.

5. Untuk memengaruhi minat konsumen agar konsumen tertarik marketing harus terlebih dahulu memberikan komunikasi yang baik terhadap konsumen, setelah itu akan menjadikan konsumen fokus terhadap apa yang disampaikan tentang penawaran dari keunggulan jasa pembiayaan multiguna Bess Finance.

\section{Saran}

Berdasarkan hasil penelitian yang penulis peroleh, maka penulis memiliki beberapa saran antara lain:

1. Penerapan Attention merupakan upaya untuk menarik perhatian konsumen agar dapat dipertahankan atau lebih ditingkatkan kembali oleh PT. Bess Finance.

2. Penerapan Interest dalam menarik minat konsumen agar selalu berusaha memertahankan keunggulan yang ada dengan menciptakan rasa ketertarikan konsumen pada jasa pembiayaan mutliguna Bess Finance.

3. Penerapan Desire merupakan upaya menciptakan suatu keinginan dari konsumen untuk mengetahui lebih lanjut tentang jasa pembiayaan multiguna Bess Finance agar selalu menawarkan keunggulan yang ada dan terus meningkatkan staregi lain yang lebih inovatif. 
4. Bagi pihak PT. Bess Finance perlu untuk terus meningkatkan penerapan AIDA agar konsumen selalu dapat mempercayai dan pada akhirnya menggunakan jasa pembiayaan multiguna Bess Finance sehingga tercipta loyalitas pelanggan.

5. Bagi perusahaan agar lebih meningkatkan perhatian dan kepedulian terhadap kegiatan komunikasi pemasaran dengan membantu dan mendukung baik sarana dan prasarana dalam menjalankan tugas pemasaran untuk memenuhi target perusahaan.

\section{DAFTAR PUSTAKA}

Bungin, Burhan. 2006 Sosiologi Komunikasi Teori, Paradigma, dan diskursus Teknologi Komunikasi di Masyarakat. Ed 1. Jakarta: Kencana Prenada Media Group

Cangara, Hafied. 2012. Pengantar Ilmu Komunikasi. Jakarta: PT Raja Grafindo Persada

Daryanto. 2010. Ilmu Komunikasi. Cet I. Bandung: Satu Nusa

Deddy Mulyana, Anwar Arifin, dan Hafied Canggara. 2011. Ilmu Komunikasi Sekarang dan Tantangan Masa Depan. Ed 1, Jakarta: Kencana Prenada Media Grup

Dewi, Eli Wuria. 2013. Hukum Perlindungan Konsumen. Yogyakarta : Graha Ilmu
Effendy, Onong, Uchjana. 2003. Ilmu, Teori dan Filsafat Komunikasi. Bandung : Cipta Aditya Bakti

Fantoni, Abdurrahmat. 2011. Metode Penelitian dan Teknik Penyusunan. Jakarta: Rineka Citra

Krisyantono, Rachmat. 2008. Riset Komunikasi. Jakarta : Prenada Media Group

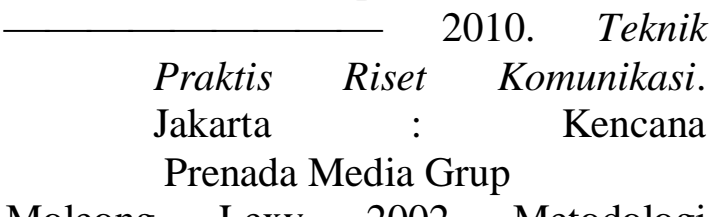

Moleong, Lexy. 2002. Metodologi Penelitian Kualitatif. Bandung: PT. remaja Rosdakarya.

2011. Metodelogi Penelitian Kualitatif. Bandung : PT Remaja Rosdakarya

Nasution, S. 2012. Metode Research. Jakarta : Bumi Angkasa

Priansa, Donni Junii, 2017. Komunikasi Pemasaran Terpadu. Pada Era Media Sosial. Bandung : Pustaka Setia

Rakhmat, Jalaluddin. 2002. Psiokologi Komunikasi. Bandung: PT. Remaja Rosadakarya

Schiffman, Leon $G$ dan Kanuk, Leslie Lazar 2008, Perilaku Konsumen, Indeks, Jakarta.

Sugiyono. 2009. Metode Penlitian Kuantitafif, Kualitatif dan $R \&$ D. Bandung : Alfabeta

Suparno. 2004. Marketing Profesional Strategi dan Trik dalam menjual Produk Jakarta : Restu Agung 